\title{
Genome-informed integrative taxonomic description of three cryptic species in the earthworm genus Carpetania (Oligochaeta, Hormogastridae)
}

\author{
Daniel Fernández Marchán ${ }^{1,2 *}$, Rosa Fernández ${ }^{3}$ Jorge Domínguez², Darío J. Díaz Cosín ${ }^{1}$, \\ Marta Novo ${ }^{1}$
}

1 Department of Biodiversity, Ecology and Evolution, Faculty of Biology, Universidad Complutense de Madrid, Madrid, Spain.

2 Current address: Departamento de Ecoloxía e Bioloxía Animal, Universidade de Vigo, Vigo, E36310, Spain

3 Animal Biodiversity and Evolution Program, Institute of Evolutionary Biology (CSIC-UPF), Passeig Marítim de la Barceloneta, 37-49, 08003 Barcelona, Spain.

* Corresponding author: daniel.fernandez.marchan@uvigo.es

\begin{abstract}
Research on cryptic species complexes has reached a consensus on the necessity of integrating multiple sources of evidence. Low-coverage genomic scan techniques like Genotyping-bySequencing (GBS) have proven useful to study these groups. Both integrative taxonomy and genomewide single nucleotide polymorphism (SNP) data remain to be widely applied to earthworms, an animal group with widespread presence of cryptic diversity. The genus Carpetania (formerly the Hormogaster elisae species complex) was found to contain six deeply divergent genetic lineages and some inconspicuous morphological differentiation based in a handful of Sanger-sequenced markers. Marchán et al. (submitted) delimited three well supported species-level clades on the basis of a genomewide SNP dataset and geometric morphometric analyses, highlighting the necessity of a formal taxonomic description of these taxa. In this work, further analyses are applied to the SNP data and a thorough morphological study is performed in order to provide an integrative description of two new species and to redescribe Carpetania elisae. Species-specific SNPs are identified and used as
\end{abstract}


diagnostic characters, and genome-wide and cytochrome oxidase C subunit 1 (COI) genetic distances are compared finding a strong correlation between them. The taxonomic description of these three cryptic species provides a useful tool to include them effectively in ecological studies and biodiversity conservation actions.

\section{Keywords}

Genotyping-by-Sequencing; integrative taxonomy; earthworms; cryptic species; soil fauna

\section{Introduction}

Since the advent of molecular phylogenetic techniques, discovery of cryptic species complexes showed a surge in scientific interest (Bickford et al., 2007; Pfenninger \& Schwenk, 2007; Trontelj \& Fišer, 2009; León, de León, \& Nadler, 2010; Nygren, 2014), followed by a stage of novelties in species delimitation methodologies including different algorithms, genetic markers and integrative approaches (Pons et al., 2006; Z. Yang \& Rannala, 2010; Puillandre, Lambert, Brouillet, \& Achaz, 2012; Zhang, Kapli, Pavlidis, \& Stamatakis, 2013; Ziheng Yang, 2015). Two main lessons can be gathered from those studies: to obtain robust species delimitation hypotheses, several information sources (molecular, morphological, ecological, ethological...) must be integrated (Queiroz \& De Queiroz, 2007); and nuclear molecular markers are necessary to rule out the possibility of confounding deep mitochondrial lineages with proper cryptic species (Dupont, Porco, Symondson, \& Roy, 2016).

Some works have already shown the potential of genome-wide single nucleotide polymorphism datasets (either generated by RADseq or GBS -Genotyping By Sequencing-) to provide rich phylogeographic and species delimitation information for cryptic species complexes (Garg et al., 2016; Brunet et al., 2017, Rancilhac et al., 2019), but have only been applied to earthworms in the Lumbricus rubellus complex (Giska, Sechi, \& Babik, 2015; Anderson, Cunha, Sechi, Kille, \& Spurgeon, 2017). The first work failed to detect differentiation between sympatric cryptic lineages, which was interpreted as these lineages not corresponding to biological species. The second work, 
performed on different lineages of the same complex, found strong differentiation between them using similar analyses.

Pervasive cryptic diversity has been found in earthworms across different families (Lumbricidae King, Andrew King, Tibble, \& Symondson, 2008; Fernández, Almodóvar, Novo, Simancas, \& Díaz Cosín, 2012; Shekhovtsov, Golovanova, \& Peltek, 2013; Porco et al., 2018; Hormogastridae - Novo, Almodóvar, Fernández, Trigo, \& Díaz Cosín, 2010; Megascolecidae - Chang, Lin, \& Chen, 2008; Buckley et al., 2011, Moniligastridae - Ganin \& Atopkin, 2018). Integrative taxonomy has yet to be widely employed in these complexes (Taheri et al., 2018).

One of the most studied cryptic species groups among these animals is the former Hormogaster elisae Álvarez, 1977, recognized as the genus Carpetania after Daniel Fernández Marchán et al., (2018). Six highly divergent cryptic lineages were identified using Sanger-sequenced mitochondrial and nuclear markers (Daniel F. Marchán, Fernández, de Sosa, Díaz Cosín, \& Novo, 2017), but their description was precluded by the absence of clear-cut limits between the putative species. Quantitative differences in the distal end of genital chaetae were discovered between those cryptic lineages through geometric morphometrics (Daniel F. Marchán, Sánchez, et al., 2016), hinting a possible pseudocryptic status for the identified lineages. Pseudocryptic species are those classified as cryptic due to the "inadequacy of the morphological analysis” (Knowlton, 1993) and can usually be distinguished after careful morphological analysis together with molecular data (Lajus, Sukhikh, \& Alekseev, 2015).

Recently, a rich genome-wide SNP dataset was obtained through GBS for seventeen populations and 85 individuals of Carpetania by Marchán et al. (submitted), with the main objective of studying selection signatures and local adaptation in the cryptic complex. The authors applied different approaches to genetic structure identification and species delimitation together with geometric morphometrics analysis (Fig. 1), finding congruent support for three species-level genetic clusters (hereafter cluster A, B and C), which comprised one or more of the six previously identified lineages as described in Daniel F. Marchán et al., (2017).

Figure 1. 
The well-supported putative species identified in Carpetania demanded a full, detailed taxonomic description: several authors have stressed the necessity of going a step further from cryptic species identification (Jörger \& Schrödl, 2013; Wang et al., 2016). To this end, this work will build upon the framework provided by Marchán et al. (submitted), with the following objectives: i) identify genomewide nucleotidic positions to be used as diagnostic characters in species description (molecular taxonomy); ii) explore further morphometric and internal anatomic characters to reinforce species description; iii) formally describe the species within Carpetania; iv) compare genomic and barcode genetic distances to validate the widespread use of the latter.

\section{Materials and methods}

\section{Molecular data}

SNP data comprising the geographical distribution and internal lineages of Carpetania was generated in Marchán et al. (submitted). In brief, GBS libraries were generated and sequenced for seventeen populations with five individuals from each totalling 85 individuals. Different datasets were generated with STACKS2 (Rochette, Rivera-Colón, \& Catchen, n.d.) based on: de novo assembly/mapping to a reference transcriptome of C. elisae ('reference-all SNPs' dataset) and inclusion of all SNPs/one random SNP per locus ('de novo-one SNP dataset).

'de novo-one SNP' and 'reference-all SNPs' datasets were further analysed in this work to estimate genetic diversity and to identify diagnostic positions, respectively.

Genetic diversity of the studied populations was described through identity by state (IBS) genetic distance within and between populations and fixation index $\left(\mathrm{F}_{\mathrm{ST}}\right)$. These parameters were obtained from the populations function (STACKS2 package) summary files. Correlation between SNP-based genetic distances and $\mathrm{F}_{\mathrm{ST}}$ and the same parameters obtained from cytochrome $\mathrm{C}$ oxidase 1 sequences (Daniel F. Marchán et al., 2017) was tested through a Mantel test in the R package vegan (Dixon, 2003). 
Diagnostic SNP positions were identified using function nucDiag in the R package spider (Brown et al., 2012) and parsed to the corresponding contig using the Carpetania elisae transcriptome after it was functionally annotated with eggNOG-mapper(Huerta-Cepas et al., 2017). Diagnostic nucleotidic positions were also identified in the molecular markers COI, 16S-tRNAs, 28S and H3 retrieved from (Daniel F. Marchán et al., 2017) following the same method.

\section{Morphological data}

-External anatomy and morphometric characters

External anatomy characters commonly used in earthworm taxonomy were studied, with special attention to average weight and number of segments (found to have strong phylogenetic signal in Hormogastridae -Daniel F. Marchán, Novo, et al., 2016). These were measured in at least five mature individuals per population in a total of 22 populations, 9 populations from Cluster A, 6 populations from Cluster B and 7 populations from Cluster C. Statistical significance of differences was evaluated using ANOVA, Fisher’s LSD and Kruskal Wallis tests in Statgraphics 18.

-Internal anatomy

Internal anatomy characters commonly used in earthworm taxonomy were studied, with special attention to the only variable internal character in the Carpetania species complex, relative position of septum 9/10 and spermathecae. In this genus, septum 9/10 can appear displaced backwards (to 10/11) in its dorsal insertion, resulting in the spermathecae of segments 9 and 10 belonging functionally to the same segment, or show an unmodified disposition separating both pairs of spermathecae. This character was studied in 22 populations as well.

\section{Results and discussion}

\section{-Genomic divergence and diagnostic positions}


Genetic divergence parameters (average IBS distances and $\mathrm{F}_{\mathrm{ST}}$ values) are represented in Fig. 2 (values can be found in suppl. Table 1). IBS distances between populations within the main clusters ranged from 0.09 to 0.15 (mean= 0.12 ) in both clusters $\mathrm{A}$ and $\mathrm{B}$, while they ranged from 0.07 to 0.22 (mean=0.17) in cluster C. IBS distances between populations of different clusters ranged between 0.15-0.24 (mean=0.20) for clusters A and B, while they ranged between 0.18-0.24 (mean=0.21) for cluster C vs A and B.

$\mathrm{F}_{\text {ST }}$ values between populations within the main clusters were lower for cluster A (0.30-0.60, mean= 0.46) than for the other two clusters (B: 0.31-0.76, mean=0.59; C: 0.30-0.75, mean=0.63). $\mathrm{F}_{\mathrm{ST}}$ values between populations of different clusters showed similar ranges for all of them (A: 0.51-0.82, mean= 0.65; B: 0.51-0.84, mean= 0.68; C: 0.55-0.79, mean=0.67). Clustering analysis of both IBS distances and $\mathrm{F}_{\mathrm{ST}}$ values (Fig. 2) recovered the same clusters as the phylogenetic inference and subsequent analyses.

Mantel test for genomic IBS distances and uncorrected pairwise COI distances showed a strong, statistically significant correlation between both sets of values $(r=0.7956, p=0.001)$. Mantel test for genomic and COI-based $\mathrm{F}_{\mathrm{ST}}$ values showed a weaker, statistically significant correlation between them $(r=0.4801, p=0.002)$.

These results suggest that divergence in COI sequence in the Carpetania species complex reflects to a significant extent genetic divergence across the whole genome, supporting the use of this molecular marker as a proxy for the identification of the cryptic species. COI barcoding (Hebert, Ratnasingham, \& de Waard, 2003) has been widely accepted by the scientific community as a fast, simple and standardized method to identify, classify and delimit species (Decaëns, Porco, Rougerie, Brown, \& James, 2013). It is worth noting that lineages identified on the basis of COI distance alone must be supported with additional molecular (nuclear markers), morphological, ecological, ethological and biogeographical evidence (Rougerie et al., 2009).

Figure 2. 
Several diagnostic SNP positions were identified: twenty-three for Cluster A, four for Cluster B and eight for Cluster C (table 1). Twenty-eight diagnostic SNP positions were assigned to the putative protein coded by the surrounding region of the variant nucleotide (table 1). Diagnostic SNP positions were found in genes with different biological functions, as regulation, transport, response to stimuli, developmental processes, cellular processes, multicellular organismal processes and metabolism among others.

A single diagnostic nucleotidic position was found for $28 \mathrm{~S}$ molecular marker, distinguishing Cluster $\mathrm{C}$ from the other two. No diagnostic positions were identified for the rest of the Sanger-sequenced molecular markers.

Species-diagnostic SNPs have been successfully identified in plants (Cullingham, Cooke, Dang, \& Coltman, 2013) and fishes (Hand et al., 2015). Even though they may appear more difficult to use for species identification than diagnostic positions in traditional Sanger-sequenced molecular markers, the cost of GBS and RAD-sequencing has lowered significantly making their use in taxonomic studies more viable. Another alternative is the development of SNP arrays based on the previously established (through GBS/RADseq) diagnostic SNPs, as an inexpensive, automatized approach.

\section{-Morphological analyses}

Studied Cluster A and Cluster B populations showed significantly different average body weights (3.03 grams vs 4.98 grams) according to the different statistical tests. However, Cluster C average body weight (3.89 grams) was statistically indistinguishable from the other two.

No significant differences were found between the average number of segments of the studied populations of Clusters A, B and C, even though Cluster B showed the smallest average (248 segments) and C showed the highest (273 segments).

The difference in average values of morphometric characters is reminiscent of the ones found between Lumbricus terrestris and its sibling species Lumbricus herculeus (James et al., 2010). As found here, differences in weight and number of segments were not clear-cut, with overlapping distributions. This 
precludes the use of these characters in the diagnosis of the cryptic species, yet they are valuable for preliminary assignment in the field.

Character states for the relative position of spermathecae and septum 9/10 (separated/not separated by septum 9/10) showed high consistency for individuals from each population. However, those character states were not shared by all populations within the clusters (Fig. 3), with the exception of cluster B -where all studied populations showed spermathecae not separated by septum 9/10. Cluster A populations showed separated spermathecae, but the most basal populations within the clade showed not separated spermathecae. For cluster C this character showed no clear pattern, with two of its internal lineages showing constant states and the third containing populations with either character state. Both described species in the sister genus Diazcosinia possess spermathecae not separated by septum 9/10, suggesting this could be the ancestral character state for Carpetania.

The complex evolution of this trait disallows its use as diagnostic taxonomic character. However, it is an interesting example of multiple independent events of regression of a character state. Spermathecae not separated by septum 9/10 due to the backward displacement of the septum appears as a derived character state present in the common ancestor of Carpetania and Diazcosinia, while spermathecae separated by septum $9 / 10$ is the most

common disposition in other species of Hormogastridae and Lumbricidae. In order to disentangle the evolutionary pressures behind these changes, it would be necessary to understand the biological advantage of both character states. Even when the mechanisms of filling and release of sperm in earthworm spermathecae is not fully known, it is likely that contraction (and subsequent increased celomic pressure) of each segment should have a role in the process. Under this assumption, spermathecae separated by a septum would function independently, while spermathecae belonging functionally to the same segment would work coordinately. This would be relevant in the context of sexual selection and hermaphroditic sexual conflict: the capability of controlling which spermathecae stores sperm from a different mate is favourable to the female part, while diminished control over this uptake would be favourable to the male part. (Novo, Almodóvar, Fernández, Gutiérrez, \& Díaz Cosín, 2010) found no evidence of differential sperm storage from different partners in each of the four 
spermathecae in Carpetania specimens from El Molar, which according to our hypothesis should have the ability to control front and back spermathecae separately. On the other hand, different sperm storage in front and back spermathecae has been observed in other earthworms (Lumbricus terrestris Koene, Pförtner, \& Michiels, 2005 -, Eisenia andrei - Porto, 2014). Further research would be needed to test this hypothesis and to propose other alternatives.

\section{Figure 3.}

\section{-Taxonomic implications}

The genetic structuring of Carpetania populations into three clearly separated clusters, characterized by significant genome-wide divergence, inconspicuous but detectable morphological differences and with no admixture between them calls for the formal taxonomic description of those clusters as species. Cluster B includes the type locality of Hormogaster (Carpetania) elisae, hence the original description is assigned to this clade. Meanwhile, Clusters A and C are described below as new species.

Phylum Annelida Lamarck, 1802

Subphylum Clitellata Michaelsen, 1919

Class Oligochaeta Grube, 1850

Superorder Megadrili Benham, 1890

Order Haplotaxida Michaelsen, 1900

Family Hormogastridae Michaelsen, 1900

Genus Carpetania Marchán, Fernández, Díaz Cosín \& Novo, 2018

Description: 
External characters- Average number of segments from 203 to 323. Average weight from $1.22 \mathrm{~g}$ to 7.6 grams. Clitellum in segments (12)13-27. Tubercula pubertatis in segments 22-25. Pigmentation absent, color: greyish-fleshy. Cephalic keels present, moderately developed. No lateral expansions of the clitellum. Chaetae disposition geminate. No genital papillae in cd. Posterior genital papillae constrained within the extension of the clitellum. Cephalic segments not imbricated.

Internal characters- First thickened septum in 6/7. Last thickened septum in 9/10. Backward displacement of dorsal insertion of septum 9/10, one or two segments. No forward displacement of dorsal insertion of septa 7/8, 8/9. Spermathecal pores in intersegments 9/10, 10/11. Spermathecae tubular, the first pair smaller, with no repetition. Seven pairs of clearly developed hearts. Three oesophageal gizzards in segments 6, 7 and 8. Five typhlosole lamellae. Genital chaetae lanceolate, with strong dorsoventral differentiation and tip ornamentation; pore present, teeth present, dorsal depression absent, ventral groves absent. First nephridia with caeca between segments 10 and 12

\section{* Names of the species are placeholders to avoid taxonomic conflicts once the manuscript is published.}

\section{Carpetania species B* Álvarez 1977}

Type material: Holotype and paratypes - 12 adult and subadult individuals collected in Siguero, Segovia, deposited by J. Álvarez in the Spanish Entomology Institute collection with numbers 46614669 and 46610-46612. Topotypes: 8 adults (UCMLT 00368-00375), 41.185 -3.6186, from a meadow in the outskirts of the village of Siguero, Segovia (Spain), collectors Darío J. Díaz Cosín, Marta Novo, Dolores Trigo.

Distribution: Northernmost Community of Madrid, Southern Segovia, Southern Soria (Fig. 4). Full list of known localities are shown in Suppl. table 2.

Phylogenetic definition: includes the common ancestor of all the populations assigned in Marchán et al. (submitted) to the cluster B, and all its descendants. Known populations are shown in Suppl. table 2. 
Reference sequences: COI - accession EF653893.1; 16S-tRNAs- accession GQ409710.1; 28S accession GQ409654.1; H3 - accession HQ622033.1.

Description:

External and internal morphological characters match the description of the genus Carpetania in all aspects but the following.

Average weight from 1.87 to 7.44 (mean= 4.98). Average number of segments from 231 to 288 (mean= 248). Generally heavier and shorter than the other species: "stout" appearance after fixation. Both pairs of spermathecae not separated by septum 9/10.

Diagnosis: Genital chaetae with an elongated, wide tip (Fig. 5). Diagnostic nucleotidic positions shown in table 1.

Remarks: this species includes specimens from Siguero, topotypes of the holotype of Hormogaster elisae. Thus, the whole species must carry this name and be the type species of the genus Carpetania.

Carpetania species A* Marchán, Novo, Férnandez and Díaz Cosín sp. nov.

Type material: Holotype. Adult (UCMLT 00386), 40.7394 -3.5647, from a meadow in the outskirts of the village of El Molar, Madrid (Spain), collectors Marta Novo, Darío J. Díaz Cosín. Paratypes. 7 adults (UCMLT 00387-00393), with the same collection data of the holotype

Distribution: Northern and Central Community of Madrid, Madrid-Guadalajara border (Fig. 4). Full list of known localities are shown in Suppl. table 2.

Phylogenetic definition: includes the common ancestor of all the populations assigned in Marchán et al. (submitted) to the cluster A, and all its descendants. Known populations are shown in Suppl. table 2.

Reference sequences: COI - accession EF653876.1; 16S-tRNAs- accession JN209295.1; 28S accession GQ409653.1; H3 - accession JN209636.1; 
Description:

External and internal morphological characters match the description of the genus Carpetania in all aspects but the following.

Average weight from 1.22 to 4.66 (mean= 3.10). Average number of segments from 203 to 285 (mean= 253). "Slender” appearance after fixation. Both pairs of spermathecae separated by septum 9/10 in most populations (except in basal clades).

Diagnosis: Genital chaetae with a shortened tip and serrated lateral ridges (Fig. 5). Diagnostic nucleotidic positions shown in table 1.

Carpetania species C* Marchán, Novo, Fernández and Díaz Cosín sp. nov.

Type material: Holotype. Adult (UCMLT 00376), 40.4306 -3.925, from a open holm oak woodland in the outskirts of the village of Boadilla del Monte, Madrid (Spain), collectors Marta Novo, Darío J. Díaz Cosín. Paratypes. 9 adults (UCMLT 00377-00385) with the same collection data of the holotype Distribution: Southern and Central Community of Madrid, Northeastern Segovia, Southwestern Soria, Northwestern Guadalajara (Fig. 4). Full list of known localities are shown in Suppl. table 2.

Phylogenetic definition: includes the common ancestor of all the populations assigned in Marchán et al. (submitted) to the cluster C, and all its descendants. Known populations are shown in Suppl. table 2.

Reference sequences: COI - accession GQ409664.1; 16S-tRNAs- accession GQ409704.1; 28S accession GQ409656.1; H3 - accession HQ622004.1;

Description:

External and internal morphological characters match the description of the genus Carpetania in all aspects but the following. 
Average weight from 1.41 to 5.60 (mean= 3.9). Average number of segments from 204 to 323 (mean= 273). Generally longer than the other species: “slender” appearance after fixation. Both pairs of spermathecae separated (or not) by septum 9/10, with variation between its internal lineages.

Diagnosis: Genital chaetae with elongated, narrow tip (Fig. 5). Diagnostic nucleotidic positions shown in table 1.

Remarks: this species includes three deeply divergent lineages. Further research on their range, ecology and other characters could merit their recognition as subspecies.

\section{Figure 4.}

\section{Figure 5.}

\section{Table 1.}

\section{-Recommendations for species identification within Carpetania}

Morphological study of traits and character states included in the descriptions and diagnoses of the different Carpetania species allow a preliminary approximation to assignment of individuals. However, there is overlap between the range of morphometric characters, and scanning electron microscopy imaging of genital chaetae is demanding for untrained researchers.

The most straightforward and effective approach to species identification would consist on sequencing one or more of the proposed reference molecular markers (COI, 16S-tRNAs, 28S, H3) and their comparison with the reference sequences provided in the descriptions. This would provide a reliable assignment to one of the species.

This method does not require expertise in earthworm taxonomy and should facilitate the inclusion of these species into community and soil ecology studies. Considering existing evidence of different ecological preferences between Carpetania species (personal communication), it is necessary that 
they are not bunched together in such analyses. It is also a requisite to evaluate the conservation status of the pseudocryptic species and to preserve the diversity of this endemic genus through conservation actions.

\section{Acknowledgments}

This work was supported by Universidad Complutense de Madrid and Santander Group under grant Proyecto de Investigación Santander/Complutense PR41/17-21027; Systematics Research Fund (SRF) and Xunta de Galicia. Consellería de Cultura, Educación e Ordenación Universitaria. Secretaria Xeral de Universidades under grant ED431B 2019/038.

RF was funded by a Marie Skłodowska-Curie Fellowship (747607). DF was funded by a Juan de La Cierva-Formación grant (FJCI-2017-32895) from the Spanish Ministry of Sciences, Innovation and Universities. MN was funded by a Postdoctoral Fellowship UCM.

\section{References}

Anderson, C., Cunha, L., Sechi, P., Kille, P., \& Spurgeon, D. (2017). Genetic variation in populations of the earthworm, Lumbricus rubellus, across contaminated mine sites. BMC Genetics, 18(1), 97.

Bickford, D., Lohman, D. J., Sodhi, N. S., Ng, P. K. L., Meier, R., Winker, K., ... Das, I. (2007). Cryptic species as a window on diversity and conservation. Trends in Ecology \& Evolution, 22(3), 148-155.

Brown, S. D. J., Collins, R. A., Boyer, S., Lefort, M.-C., Malumbres-Olarte, J., Vink, C. J., \& Cruickshank, R. H. (2012). Spider: An R package for the analysis of species identity and evolution, with particular reference to DNA barcoding. Molecular Ecology Resources, Vol. 12, pp. 562-565. https://doi.org/10.1111/j.1755-0998.2011.03108.x

Brunet, B. M. T., Blackburn, G. S., Muirhead, K., Lumley, L. M., Boyle, B., Lévesque, R. C., ... Sperling, F. A. H. (2017). Two’s company, three's a crowd: new insights on spruce budworm 
species boundaries using genotyping-by-sequencing in an integrative species assessment (Lepidoptera: Tortricidae). Systematic Entomology, Vol. 42, pp. 317-328. https://doi.org/10.1111/syen.12211

Buckley, T. R., James, S., Allwood, J., Bartlam, S., Howitt, R., \& Prada, D. (2011). Phylogenetic analysis of New Zealand earthworms (Oligochaeta: Megascolecidae) reveals ancient clades and cryptic taxonomic diversity. Molecular Phylogenetics and Evolution, 58(1), 85-96.

Chang, C.-H., Lin, S.-M., \& Chen, J.-H. (2008). Molecular systematics and phylogeography of the gigantic earthworms of the Metaphire formosae species group (Clitellata, Megascolecidae). Molecular Phylogenetics and Evolution, 49(3), 958-968.

Cullingham, C. I., Cooke, J. E. K., Dang, S., \& Coltman, D. W. (2013). A species-diagnostic SNP panel for discriminating lodgepole pine, jack pine, and their interspecific hybrids. Tree Genetics \& Genomes, Vol. 9, pp. 1119-1127. https://doi.org/10.1007/s11295-013-0608-x

Decaëns, T., Porco, D., Rougerie, R., Brown, G. G., \& James, S. W. (2013). Potential of DNA barcoding for earthworm research in taxonomy and ecology. Applied Soil Ecology, Vol. 65, pp. 35-42. https://doi.org/10.1016/j.apsoil.2013.01.001

Dixon, P. (2003). VEGAN, a package of R functions for community ecology. Journal of Vegetation Science, Vol. 14, p. 927. https://doi.org/10.1658/1100-9233(2003)014[0927:vaporf]2.0.co;2

Dupont, L., Porco, D., Symondson, W. O. C., \& Roy, V. (2016). Hybridization relics complicate barcode-based identification of species in earthworms. Molecular Ecology Resources, 16(4), 883-894.

Fernández, R., Almodóvar, A., Novo, M., Simancas, B., \& Díaz Cosín, D. J. (2012). Adding complexity to the complex: new insights into the phylogeny, diversification and origin of parthenogenesis in the Aporrectodea caliginosa species complex (Oligochaeta, Lumbricidae). Molecular Phylogenetics and Evolution, 64(2), 368-379.

Ganin, G. N., \& Atopkin, D. M. (2018). Molecular differentiation of epigeic and anceic forms of Drawida ghilarovi Gates, 1969 (Moniligastridae, Clitellata) in the Russian Far East: Sequence data of two mitochondrial genes. European Journal of Soil Biology, Vol. 86, pp. 1-7. https://doi.org/10.1016/j.ejsobi.2018.02.004 
Garg, K. M., Tizard, R., Ng, N. S. R., Cros, E., Dejtaradol, A., Chattopadhyay, B., ... Rheindt, F. E. (2016). Genome-wide data help identify an avian species-level lineage that is morphologically and vocally cryptic. Molecular Phylogenetics and Evolution, 102, 97-103.

Giska, I., Sechi, P., \& Babik, W. (2015). Deeply divergent sympatric mitochondrial lineages of the earthworm Lumbricus rubellus are not reproductively isolated. BMC Evolutionary Biology, Vol. 15. https://doi.org/10.1186/s12862-015-0488-9

Hand, B. K., Hether, T. D., Kovach, R. P., Muhlfeld, C. C., Amish, S. J., Boyer, M. C., ... Luikart, G. (2015). Genomics and introgression: Discovery and mapping of thousands of species-diagnostic SNPs using RAD sequencing. Current Zoology, Vol. 61, pp. 146-154. https://doi.org/10.1093/czoolo/61.1.146

Hebert, P. D. N., Ratnasingham, S., \& de Waard, J. R. (2003). Barcoding animal life: cytochrome c oxidase subunit 1 divergences among closely related species. Proceedings of the Royal Society of London. Series B: Biological Sciences, Vol. 270. https://doi.org/10.1098/rsbl.2003.0025

Huerta-Cepas, J., Forslund, K., Coelho, L. P., Szklarczyk, D., Jensen, L. J., von Mering, C., \& Bork, P. (2017). Fast Genome-Wide Functional Annotation through Orthology Assignment by eggNOG-Mapper. Molecular Biology and Evolution, 34(8), 2115-2122.

James, S. W., Porco, D., Decaëns, T., Richard, B., Rougerie, R., \& Erséus, C. (2010). DNA barcoding reveals cryptic diversity in Lumbricus terrestris L., 1758 (Clitellata): resurrection of L. herculeus (Savigny, 1826). PloS One, 5(12), e15629.

Jörger, K. M., \& Schrödl, M. (2013). How to describe a cryptic species? Practical challenges of molecular taxonomy. Frontiers in Zoology, 10(1), 59.

King, R. A., Andrew King, R., Tibble, A. L., \& Symondson, W. O. C. (2008). Opening a can of worms: unprecedented sympatric cryptic diversity within British lumbricid earthworms. Molecular Ecology, Vol. 17, pp. 4684-4698. https://doi.org/10.1111/j.1365-294x.2008.03931.x Knowlton, N. (1993). Sibling Species in the Sea. Annual Review of Ecology and Systematics, Vol. 24, pp. 189-216. https://doi.org/10.1146/annurev.es.24.110193.001201

Koene, J. M., Pförtner, T., \& Michiels, N. K. (2005). Piercing the partner’s skin influences sperm uptake in the earthworm Lumbricus terrestris. Behavioral Ecology and Sociobiology, Vol. 59, pp. 
243-249. https://doi.org/10.1007/s00265-005-0030-y

Lajus, D., Sukhikh, N., \& Alekseev, V. (2015). Cryptic or pseudocryptic: can morphological methods inform copepod taxonomy? An analysis of publications and a case study of theEurytemora affinisspecies complex. Ecology and Evolution, Vol. 5, pp. 2374-2385.

https://doi.org/10.1002/ece3.1521

León, G. P.-P. de, de León, G. P.-P., \& Nadler, S. A. (2010). What We Don’t Recognize Can Hurt Us: A Plea for Awareness About Cryptic Species. Journal of Parasitology, Vol. 96, pp. 453-464. https://doi.org/10.1645/ge-2260.1

Marchán, D. F., Fernández, R., de Sosa, I., Díaz Cosín, D. J., \& Novo, M. (2017). Pinpointing cryptic borders: Fine-scale phylogeography and genetic landscape analysis of the Hormogaster elisae complex (Oligochaeta, Hormogastridae). Molecular Phylogenetics and Evolution, 112, 185-193.

Marchán, D. F., Fernández, R., de Sosa, I., Sánchez, N., Díaz Cosín, D. J., \& Novo, M. (2018). Integrative systematic revision of a Mediterranean earthworm family: Hormogastridae (Annelida, Oligochaeta). Invertebrate Systematics, Vol. 32, p. 652. https://doi.org/10.1071/is17048

Marchán, D. F., Novo, M., Fernández, R., de Sosa, I., Trigo, D., \& Díaz Cosín, D. J. (2016). Evaluating evolutionary pressures and phylogenetic signal in earthworms: a case study - the number of typhlosole lamellae in Hormogastridae (Annelida, Oligochaeta). Zoological Journal of the Linnean Society, Vol. 178, pp. 4-14. https://doi.org/10.1111/zoj.12410

Marchán, D. F., Sánchez, N., Novo, M., Fernández, R., Pardos, F., \& Díaz Cosín, D. J. (2016). Cryptic characters for cryptic taxa: On the taxonomic utility of the genital chaetae in earthworms (Oligochaeta, Hormogastridae). Zoologischer Anzeiger - A Journal of Comparative Zoology, Vol. 264, pp. 17-28. https://doi.org/10.1016/j.jcz.2016.06.008

Novo, M., Almodóvar, A., Fernández, R. M., Gutiérrez, M., \& Díaz Cosín, D. J. (2010). Mate choice of an endogeic earthworm revealed by microsatellite markers. Pedobiologia, Vol. 53, pp. 375379. https://doi.org/10.1016/j.pedobi.2010.07.002

Novo, M., Almodóvar, A., Fernández, R., Trigo, D., \& Díaz Cosín, D. J. (2010). Cryptic speciation of hormogastrid earthworms revealed by mitochondrial and nuclear data. Molecular Phylogenetics 
and Evolution, Vol. 56, pp. 507-512. https://doi.org/10.1016/j.ympev.2010.04.010

Nygren, A. (2014). Cryptic polychaete diversity: a review. Zoologica Scripta, Vol. 43, pp. 172-183. https://doi.org/10.1111/zsc.12044

Pfenninger, M., \& Schwenk, K. (2007). Cryptic animal species are homogeneously distributed among taxa and biogeographical regions. BMC Evolutionary Biology, 7, 121.

Pons, J., Barraclough, T. G., Gomez-Zurita, J., Cardoso, A., Duran, D. P., Hazell, S., ... Vogler, A. P. (2006). Sequence-based species delimitation for the DNA taxonomy of undescribed insects. Systematic Biology, 55(4), 595-609.

Porco, D., Chang, C.-H., Dupont, L., James, S., Richard, B., \& Decaëns, T. (2018). A reference library of DNA barcodes for the earthworms from Upper Normandy: Biodiversity assessment, new records, potential cases of cryptic diversity and ongoing speciation. Applied Soil Ecology, Vol. 124, pp. 362-371. https://doi.org/10.1016/j.apsoil.2017.11.001

Porto, P. G. (2014). La selección sexual post-cópula en la lombriz roja (Eisenia andrei Bouché, 1972) (Doctoral dissertation, Universidade de Vigo).

Puillandre, N., Lambert, A., Brouillet, S., \& Achaz, G. (2012). ABGD, Automatic Barcode Gap Discovery for primary species delimitation. Molecular Ecology, 21(8), 1864-1877.

Queiroz, K. D., \& De Queiroz, K. (2007). Species Concepts and Species Delimitation. Systematic Biology, Vol. 56, pp. 879-886. https://doi.org/10.1080/10635150701701083

Rancilhac, L., Goudarzi, F., Gehara, M., Hemami, M.-R., Elmer, K. R., Vences, M., \& Steinfarz, S. (2019). Phylogeny and species delimitation of near Eastern Neurergus newts (Salamandridae) based on genome-wide RADseq data analysis. Molecular Phylogenetics and Evolution, 133, 189-197.

Rochette, N. C., Rivera-Colón, A. G., \& Catchen, J. M. (n.d.). Stacks 2: Analytical Methods for Paired-end Sequencing Improve RADseq-based Population Genomics. https://doi.org/10.1101/615385

Rougerie, R., Decaëns, T., Deharveng, L., Porco, D., James, S. W., Chang, C.-H., ... Hebert, P. D. N. (2009). DNA barcodes for soil animal taxonomy. Pesquisa Agropecuária Brasileira, Vol. 44, pp. 789-802. https://doi.org/10.1590/s0100-204x2009000800002 
Shekhovtsov, S. V., Golovanova, E. V., \& Peltek, S. E. (2013). Cryptic diversity within the Nordenskiold’s earthworm, Eisenia nordenskioldi subsp. nordenskioldi (Lumbricidae, Annelida). European Journal of Soil Biology, Vol. 58, pp. 13-18. https://doi.org/10.1016/j.ejsobi.2013.05.004

Taheri, S., James, S., Roy, V., Decaëns, T., Williams, B. W., Anderson, F., ... Dupont, L. (2018). Complex taxonomy of the "brush tail" peregrine earthworm Pontoscolex corethrurus. Molecular Phylogenetics and Evolution, 124, 60-70.

Trontelj, P., \& Fišer, C. (2009). Perspectives: Cryptic species diversity should not be trivialised. Systematics and Biodiversity, Vol. 7, pp. 1-3. https://doi.org/10.1017/s1477200008002909 Wang, Y., Zhou, Q.-S., Qiao, H.-J., Zhang, A.-B., Yu, F., Wang, X.-B., ... Zhang, Y.-Z. (2016). Formal nomenclature and description of cryptic species of the Encyrtus sasakii complex (Hymenoptera: Encyrtidae). Scientific Reports, 6, 34372.

Yang, Z. (2015). The BPP program for species tree estimation and species delimitation. Current Zoology, Vol. 61, pp. 854-865. https://doi.org/10.1093/czoolo/61.5.854

Yang, Z., \& Rannala, B. (2010). Bayesian species delimitation using multilocus sequence data.

Proceedings of the National Academy of Sciences, Vol. 107, pp. 9264-9269. https://doi.org/10.1073/pnas.0913022107

Zhang, J., Kapli, P., Pavlidis, P., \& Stamatakis, A. (2013). A general species delimitation method with applications to phylogenetic placements. Bioinformatics , 29(22), 2869-2876. 


\section{Tables}

\begin{tabular}{|c|c|c|c|c|}
\hline \multirow{2}{*}{$\begin{array}{l}\text { SNP } \\
\text { Cluster A }\end{array}$} & \multicolumn{2}{|l|}{ Scaffold } & \multirow[t]{2}{*}{ Base } & \multirow[t]{2}{*}{ Protein } \\
\hline & & & & \\
\hline 344 & COMP190067_C0_SEQ1 & 395 & $\mathrm{~T} / \mathrm{C}$ & \\
\hline 727 & COMP206745_C0_SEQ1 & 527 & G/A & Retinol binding protein \\
\hline 784 & COMP207582_C0_SEQ2 & 792 & $\mathrm{G} / \mathrm{C}$ & $\begin{array}{l}\text { SWAP switching B-cell complex } \\
\text { 70kDa subunit }\end{array}$ \\
\hline 949 & COMP209848_C1_SEQ1 & 269 & $T / G$ & \\
\hline 1009 & COMP210899_CO_SEQ5 & 908 & $\mathrm{~A} / \mathrm{T}$ & $\begin{array}{l}\text { Zinc finger, FYVE domain } \\
\text { containing } 20\end{array}$ \\
\hline 1113 & COMP211847_C2_SEQ1 & 3393 & $A / G$ & $\begin{array}{l}\text { ATP-binding cassette, } \\
\text { subfamily B (MDR TAP), } \\
\text { member }\end{array}$ \\
\hline 1291 & COMP213230_C0_SEQ4 & 658 & $\mathrm{~T} / \mathrm{C}$ & \\
\hline 1409 & COMP213929_CO_SEQ2 & 1505 & $A / G$ & nuclear respiratory factor 1 \\
\hline 1425 & COMP214029_CO_SEQ1 & 1951 & $\mathrm{~T} / \mathrm{C}$ & $\begin{array}{l}\text { NADP-dependent } \\
\text { oxidoreductase domain } \\
\text { containing } 1\end{array}$ \\
\hline 1624 & COMP215394_C0_SEQ1 & 978 & $\mathrm{~T} / \mathrm{C}$ & \\
\hline 1784 & COMP216453_C0_SEQ4 & 1281 & $\mathrm{G} / \mathrm{C}$ & \\
\hline 1814 & COMP216630_C0_SEQ7 & 1725 & $\mathrm{C} / \mathrm{T}$ & $\begin{array}{l}\text { leucine rich repeat and Ig } \\
\text { domain containing } 4\end{array}$ \\
\hline 1842 & COMP216828_C1_SEQ13 & 4668 & $\mathrm{G} / \mathrm{C}$ & $\begin{array}{l}\text { Protein phosphatase } 1 \\
\text { regulatory subunit } 37\end{array}$ \\
\hline 2127 & COMP218319_C1_SEQ44 & 2385 & $\mathrm{~T} / \mathrm{C}$ & Armadillo repeat containing 4 \\
\hline 2169 & COMP218535_C0_SEQ2 & 1141 & $\mathrm{C} / \mathrm{G}$ & $\begin{array}{l}\text { Enzyme required for electron } \\
\text { transfer from NADP to } \\
\text { cytochrome P450 }\end{array}$ \\
\hline 2267 & COMP219108_C2_SEQ1 & 3021 & $A / G$ & $\begin{array}{l}\text { SH3-domain binding protein } 5 \\
\text { (BTK-associated) }\end{array}$ \\
\hline 2417 & COMP219800_C0_SEQ6 & 2892 & $\mathrm{~A} / \mathrm{C}$ & $\begin{array}{l}\text { CREB regulated transcription } \\
\text { coactivator } 1\end{array}$ \\
\hline 2609 & COMP220400_C0_SEQ6 & 2547 & $A / C$ & Nucleoporin $54 \mathrm{kDa}$ \\
\hline 2639 & COMP220522_C0_SEQ13 & 4055 & $\mathrm{G} / \mathrm{T}$ & ubiquitin- specific peptidase \\
\hline 2652 & COMP220555_CO_SEQ8 & 3693 & $\mathrm{~T} / \mathrm{C}$ & integrator complex subunit 1 \\
\hline 2712 & COMP220746_C1_SEQ15 & 359 & $\mathrm{~T} / \mathrm{C}$ & crumbs homolog 2 (Drosophila) \\
\hline 2800 & COMP220908_CO_SEQ3 & 6612 & $A / T$ & $\begin{array}{l}\text { small nuclear RNA activating } \\
\text { complex, polypeptide } 4 \text {, } \\
\text { 190kDa }\end{array}$ \\
\hline 3071 & COMP62959_C0_SEQ1 & 45 & $A / G$ & \\
\hline Cluster B & & & & \\
\hline 195 & COMP1730661_CO_SEQ1 & 182 & $\mathrm{~T} / \mathrm{G}$ & \\
\hline
\end{tabular}




\begin{tabular}{|c|c|c|c|c|}
\hline 1410 & COMP213937_C2_SEQ1 & 662 & $\mathrm{~T} / \mathrm{C}$ & $\begin{array}{l}\text { Solute carrier family } 25 \\
\text { member }\end{array}$ \\
\hline 1512 & COMP214730_C0_SEQ1 & 1067 & $T / G$ & Peptidase family M41 \\
\hline 2800 & COMP220908_CO_SEQ3 & 6612 & $T / A$ & $\begin{array}{l}\text { small nuclear RNA activating } \\
\text { complex, polypeptide } 4 \text {, } \\
\text { 190kDa }\end{array}$ \\
\hline \multicolumn{5}{|l|}{ Cluster C } \\
\hline 491 & COMP200542_C1_SEQ2 & 499 & $\mathrm{~A} / \mathrm{C}$ & $\begin{array}{l}\text { Galactose binding lectin } \\
\text { domain }\end{array}$ \\
\hline 782 & COMP207582_CO_SEQ2 & 710 & $\mathrm{G} / \mathrm{T}$ & $\begin{array}{l}\text { SWAP switching B-cell complex } \\
\text { 70kDa subunit }\end{array}$ \\
\hline 893 & COMP209092_C1_SEQ1 & 734 & $A / T$ & phosphodiesterase PDE8B \\
\hline 1277 & COMP213187_C0_SEQ1 & 867 & $\mathrm{G} / \mathrm{A}$ & $\begin{array}{l}\text { Organic Anion Transporter } \\
\text { Polypeptide (OATP) family }\end{array}$ \\
\hline 2169 & COMP218535_C0_SEQ2 & 1141 & $\mathrm{G} / \mathrm{C}$ & $\begin{array}{l}\text { Enzyme required for electron } \\
\text { transfer from NADP to } \\
\text { cytochrome P450 }\end{array}$ \\
\hline 2397 & COMP219681_C0_SEQ1 & 375 & G/A & $\begin{array}{l}\text { PRP40 pre-mRNA processing } \\
\text { factor } 40 \text { homolog }\end{array}$ \\
\hline 2430 & COMP219875_C0_SEQ3 & 3810 & $\mathrm{C} / \mathrm{T}$ & collagen, type XII, alpha 1 \\
\hline 2776 & COMP220864_C4_SEQ4 & 4882 & $G / A$ & kiaa2026 \\
\hline
\end{tabular}

Table 1. Diagnostic nucleotidic positions for the three species of the genus Carpetania. First nucleotide is the character state found on the species and the second nucleotide is the state for the rest of the species. Putative protein coded by the contig in where diagnostic positions are located is indicated when annotation is available. 


\section{Figure captions}

Figure 1. Different approaches to genetic structure identification and species delimitation in the Carpetania complex (modified from Marchán et al. submitted). Previously defined cryptic lineages (Daniel F. Marchán et al., 2017) are represented by a colour and roman number. Color codes and nomenclature are kept throughout the manuscript. a) Maximum likelihood inference of the phylogenetic relationships of the studied populations of Carpetania. Solid outlines indicate the species-level genetic clusters (A, B, C) found by the other analyses b) Principal Component Analysis (PCA) c) Barplot of STRUCTURE analysis. Each color shows percentage of assignment to a cluster or ancestral population. d) Canonical variate analysis of the shape of the genital chaetae of Carpetania main genetic clusters.

Figure 2. Heatmap and clustering graphs displaying FST values (left) and Identity by state (IBS) distances (right) between populations of Carpetania obtained from genome-wide SNPs.

Figure 3. Relative position of spermathecae and septum $9 / 10$ for the populations included in the phylogenetic analysis. A hypothetical position of the sister genus Diazcosinia (not included in the phylogenetic reconstruction) and its character state are shown by a dashed line. Lineages from (Daniel F. Marchán et al., 2017) are shown with the same code and colors (roman numbers, dashed outlines). Species-level clusters are represented by solid outlines and letters A, B, C.

Figure 4. Known distribution of the three species of Carpetania.

Figure 5. Genital chaetae distal end from representatives of the three species in Carpetania: a) Carpetania species B, b) Carpetania species A, c) Carpetania species C. Black and white dots show the landmarks used in geometric morphometrics analyses for reference. Scale bar: $10 \mu \mathrm{m}$. 


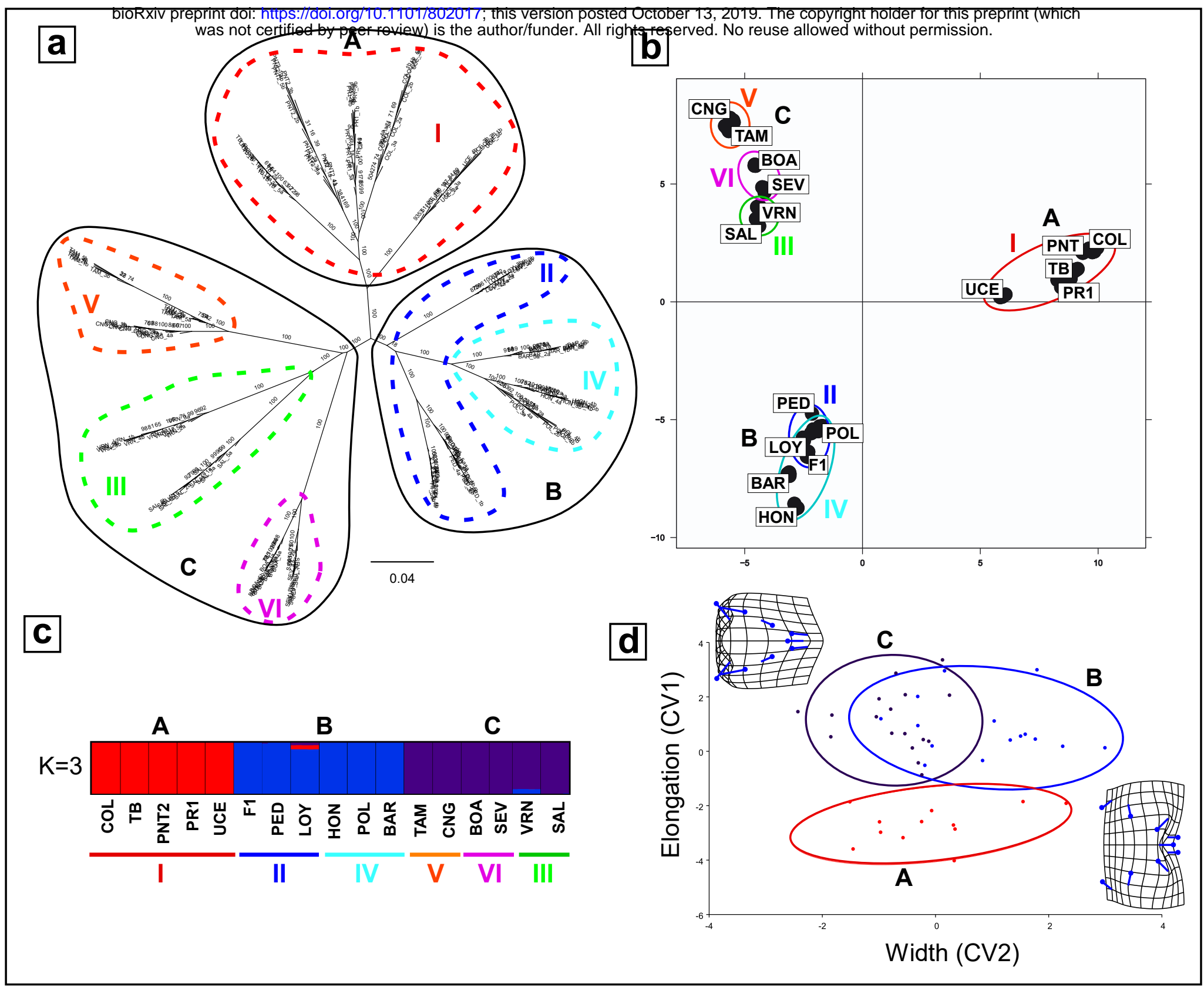


FST 0.84

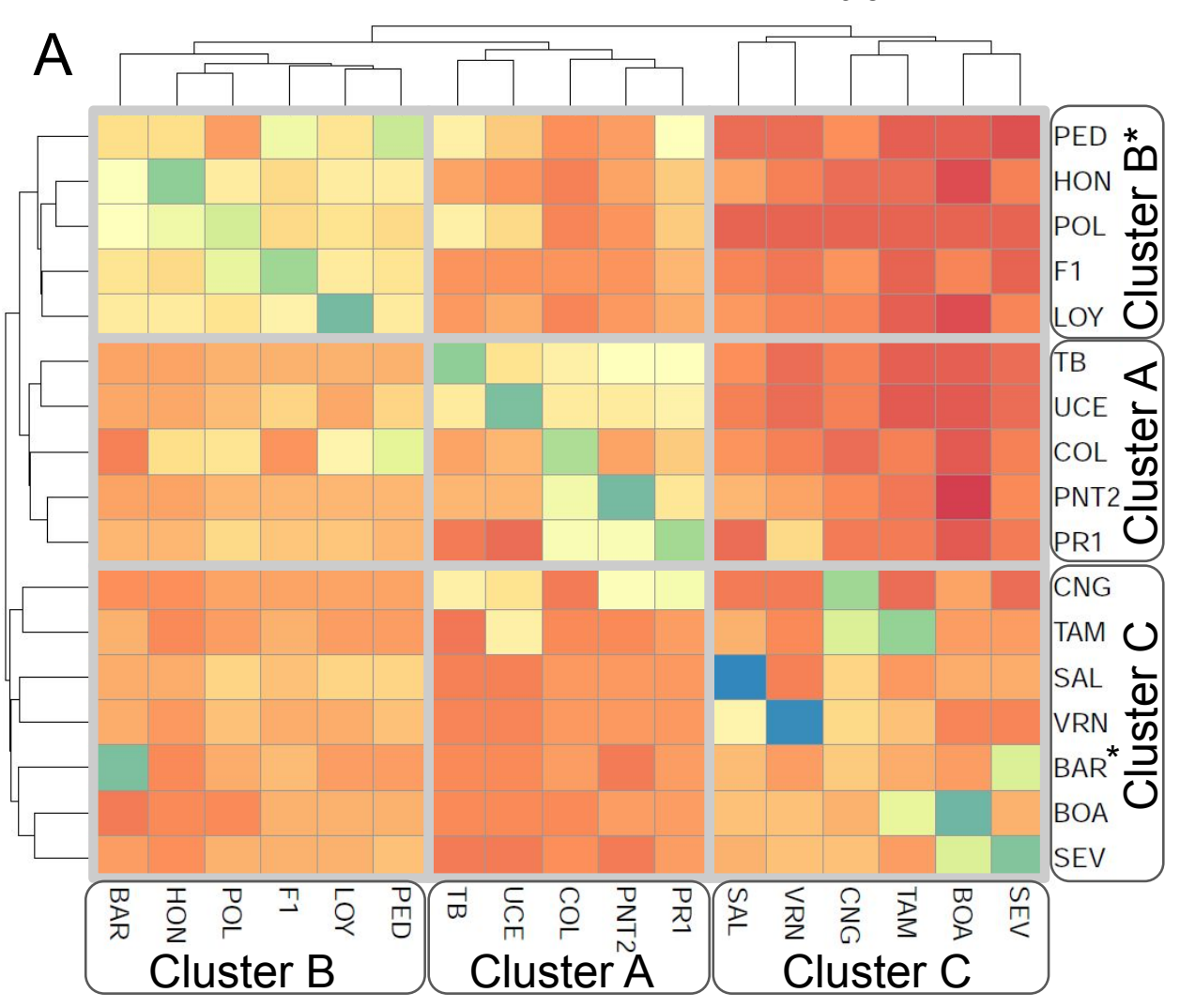

0.3

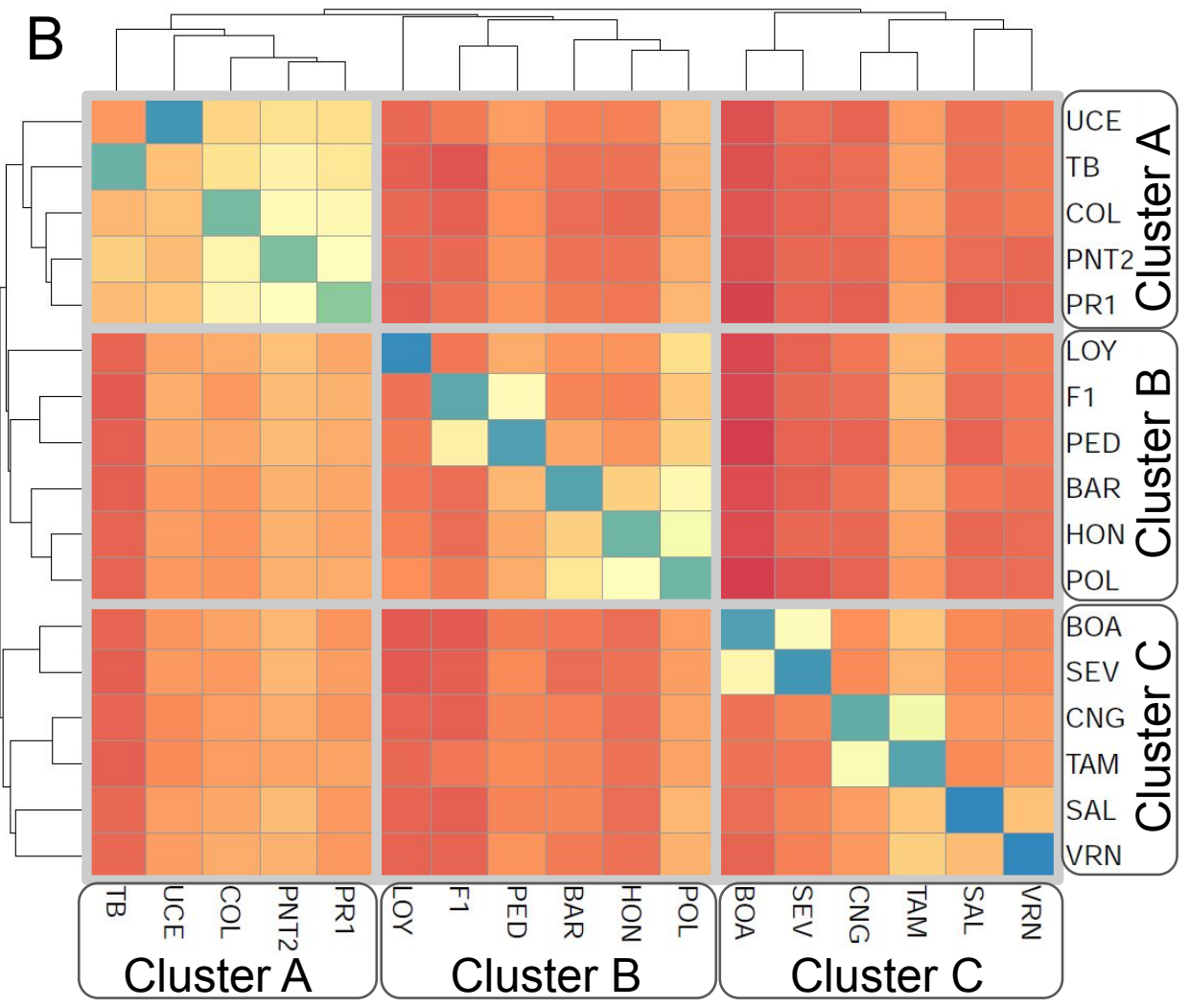




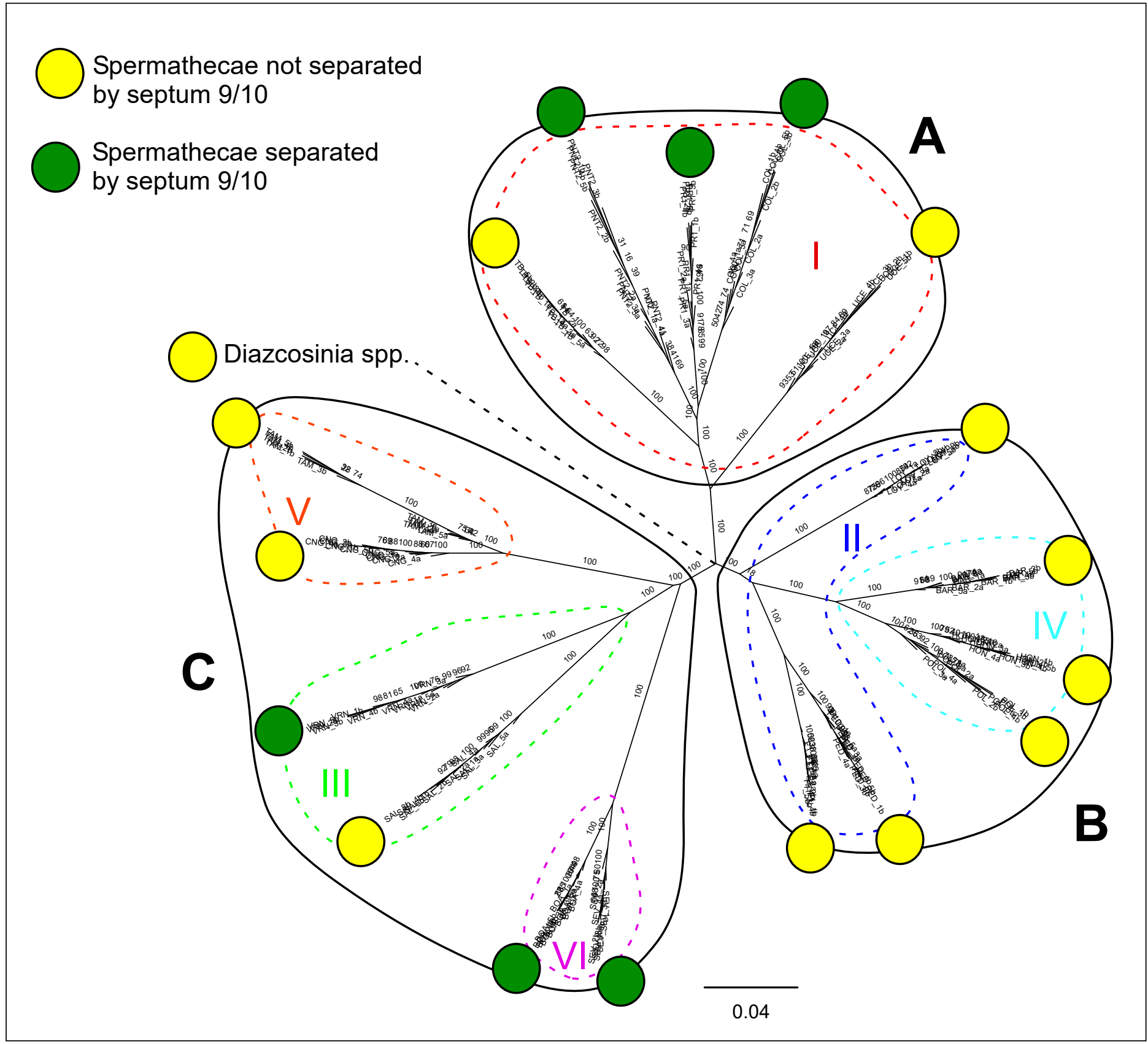




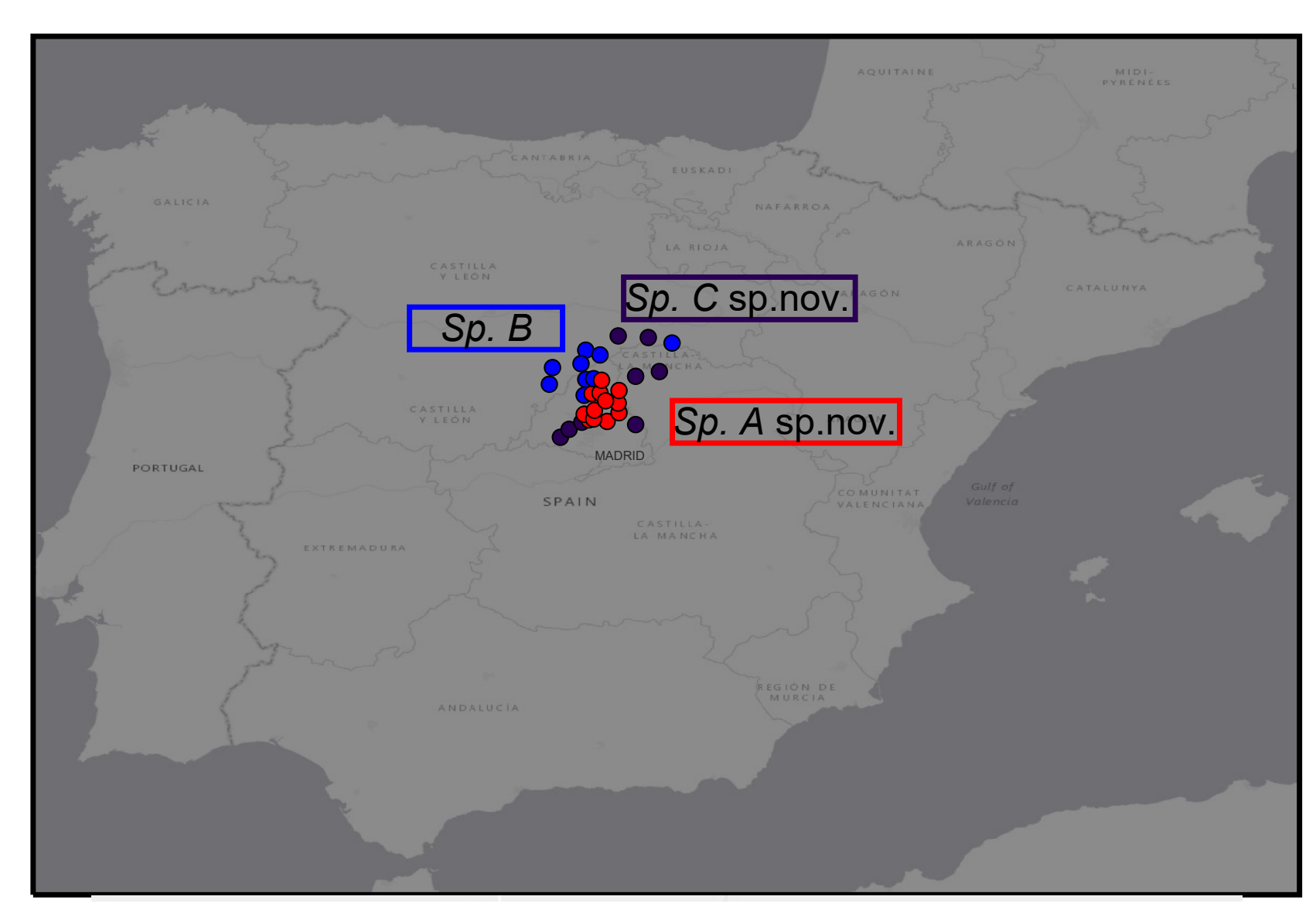




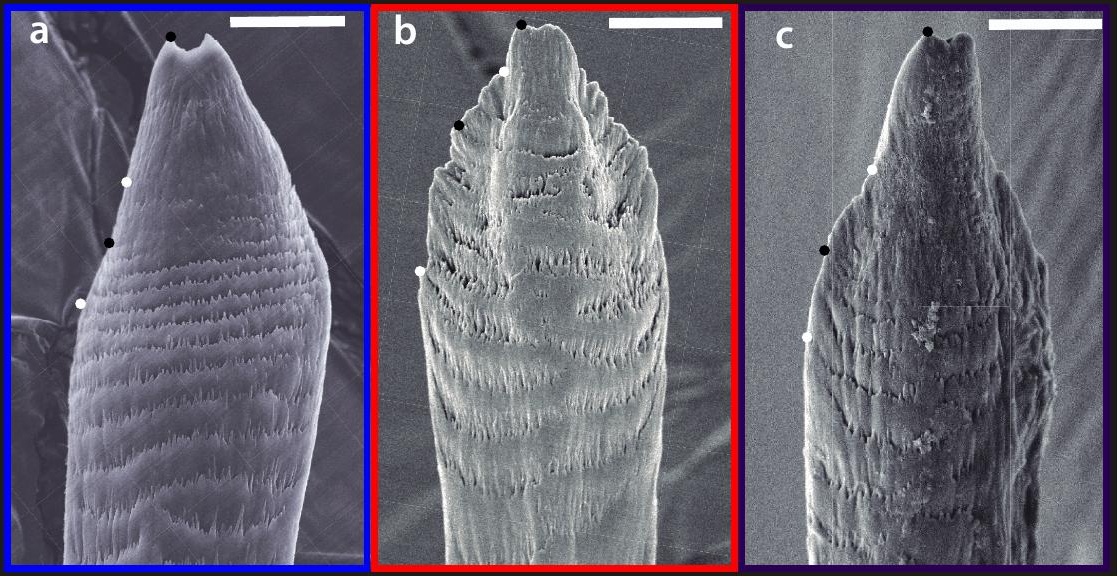

